\title{
Selective G-Protein Regulation of Neuronal Calcium Channels
}

\author{
Peter T. Toth, ${ }^{1}$ Lee R. Shekter, ${ }^{1}$ Gloria Hui Ma, ${ }^{1}$ Louis H. Philipson, ${ }^{2}$ and Richard J. Miller ${ }^{1}$ \\ ${ }^{1}$ Department of Pharmacological and Physiological Sciences, and '2Department of Medicine, The University of Chicago, \\ Chicago, Illinois 60637
}

We examined the properties and regulation of $\mathrm{Ca}$ channels resulting from the expression of human $\alpha_{1 \mathrm{~B}}$ and $\alpha_{1 \mathrm{E}}$ subunits stably expressed in HEK293 cells. The ancillary subunits $\beta_{1 \mathrm{~B}}$ and $\alpha_{2} / \delta$ were also stably expressed in these cell lines. $\mathrm{Ca}$ currents in $\alpha_{1 \mathrm{~B}}$-expressing cells had the properties of $\mathrm{N}$-type currents. Ca currents in cells expressing $\alpha_{1 \mathrm{E}}$ exhibited a novel profile that was similar to the properties of the "R type" $\mathrm{Ca}$ current. Introduction of GTP- $\gamma-\mathrm{S}$ into $\alpha_{1 \mathrm{~B}}$ cells greatly enhanced the extent of prepulse facilitation of the $\mathrm{Ca}$ current, whereas it had only a very small effect in $\alpha_{1 \mathrm{E}}$-expressing cells. Activation of somatostatin receptors endogenous to HEK293 cells or $\kappa$ opioid receptors, expressed in the cells after transfection, inhibited $\mathrm{Ca}$ currents in $\alpha_{1 \mathrm{~B}}$-expressing cells. This inhibition was blocked by pertussis toxin and was partially relieved by a depolarizing prepulse. In contrast, no inhibitory effects were noted in cells expressing $\alpha_{1 \mathrm{E}}$ channels under the same circumstances. HEK293 cells normally contained G-proteins from all of the four major families. Inhibition of $\mathrm{Ca}$ currents by $\kappa$ agonists in $\alpha_{1 \mathrm{~B}}$-expressing cells was enhanced slightly by the cotransfection of several G-protein $\alpha$ subunits. $\kappa$ agonists, however, had no effect in $\alpha_{1 \mathrm{E}}$-containing cells, even after overexpression of different G-protein $\alpha$-subunits. In summary, these results demonstrate that there is a large difference in the susceptibility of $\alpha_{1 \mathrm{~B}^{-}}$and $\alpha_{1 \mathrm{E}}$-based $\mathrm{Ca}$ channels to regulation by $\mathrm{G}$-proteins. This is so despite the fact that the two types of $\mathrm{Ca}$ channels show substantial similarities in their primary sequences.

Key words: Ca channel; G-protein; к receptor; patch clamp; HEK293; somatostatin
Regulation by receptors, G-proteins, and second messengers is one of the most widely observed characteristics of Ca channels (Hille, 1994; Dolphin, 1995). For example, the activation of L channels in the heart by cAMP-dependent phosphorylation has been studied extensively, and the physiological significance of these observations is clear (Perez-Reyes et al., 1994). In the nervous system, it has been shown frequently that activation of various G-protein-linked receptors can produce inhibition of $\mathrm{N}$ channels (Hille, 1994). Because it is known that $\mathrm{N}$ channels play a critical role in the regulation of transmitter release at many synapses (Miller, 1990; Hille, 1994), this process is believed to be a key element in the receptor regulation of synaptic communication, particularly the phenomenon of presynaptic inhibition. Rather than being mediated by a diffusible second messenger, "rapid" inhibition of $\mathrm{N}$ channels is thought to be attributable to direct effects of G-protein subunits on some part of the $\mathrm{Ca}$ channel complex (Hille, 1994). Therefore, this type of N-channel regulation has been described as "membrane delimited." It is not yet clear, however, which subunits of the G-protein heterotrimer actually produce these effects or to which part of the $\mathrm{N}$ channel they bind (Sternweis, 1994; Wickman and Clapham, 1995).

$\mathrm{N}$ channels, which result from the expression of the $\alpha_{1 \mathrm{~B}} \mathrm{Ca}$ channel subunit, are found primarily in neurons and neuroendocrine cells (Williams et al., 1992; Wheeler et al., 1995). This is also the case for at least two other types of Ca channels: the P/Q type,

Received Feb. 15, 1996; revised April 18, 1996; accepted May 2, 1996.

This work was supported by Public Health Service Grants DA02121, MH40165, DA02575, and NS33502. We thank Drs. Michael Harpold (SIBIA Inc.) and David Lodge (Eli Lilly) for providing the cell lines and for helpful discussions. We thank Dongjun Ren for her technical help.

Correspondence should be addressed to Richard J. Miller, Department of Pharmacological and Physiological Sciences, The University of Chicago, 947 East 58th Street (MC 0926), Chicago, IL 60637.

Copyright (C) 1996 Society for Neuroscience $0270-6474 / 96 / 164617-08 \$ 05.00 / 0$ which probably results from the expression of $\alpha_{1 \mathrm{~A}}$, and the recently described $\alpha_{1 \mathrm{E}}$ subunit, which may produce a Ca current of the "R" type (Williams et al., 1994; Wheeler et al., 1995). Interestingly, the $\alpha_{1 \mathrm{~A}}, \alpha_{1 \mathrm{~B}}$, and $\alpha_{1 \mathrm{E}}$ subunits form a Ca channel subfamily and exhibit a high degree of sequence homology (Dolphin, 1995; Wheeler et al., 1995). None of these Ca channels are sensitive to dihydropyridines, which block $\alpha_{1 \mathrm{C}}, \alpha_{1 \mathrm{D}}$, and $\alpha_{1 \mathrm{~S}} \mathrm{Ca}$ channels and to which they exhibit less sequence homology (Dolphin, 1995; Wheeler et al., 1995). It is now clear that Ca currents of the $\mathrm{P} / \mathrm{Q}$ type, which can also support neurotransmitter release (Wheeler et al., 1994), are regulated by G-proteins and receptors in a manner similar to N channels (Mintz and Bean, 1993; Rhim and Miller, 1994; Kanemasa et al., 1995). It is not known at this point, however, whether Ca currents resulting from the expression of $\alpha_{1 \mathrm{E}}$ are also regulated in this way. Indeed, very little is known about the properties and biological functions of $\mathrm{Ca}$ channels resulting from $\alpha_{1 \mathrm{E}}$ expression. We have now investigated this question and demonstrate that there seem to be considerable differences in the ability of $\alpha_{1 \mathrm{~B}}$ and $\alpha_{1 \mathrm{E}}$ to be regulated by G-proteins.

\section{MATERIALS AND METHODS}

HEK293 cell lines. HEK293 cell lines expressing Ca channels with various subunit compositions were kindly provided by SIBIA Inc. (Williams et al., 1992; Bleakman et al., 1995). Briefly, the cell lines were developed by stable co-transfection of HEK293 cells with human $\alpha_{1}, \alpha_{2 \mathrm{~B}} \delta$, and $\beta$ Ca channel subunit expression plasmids. The G1A1 cell line consisted of $\alpha_{1 \mathrm{~B}-1}-\alpha_{2 \mathrm{~B}} \delta-\beta_{1 \mathrm{~B}}$ subunits. The subunit composition of the A4A2 cells was $\alpha_{1 \mathrm{~B}-1}-\alpha_{2 \mathrm{~B}} \delta-\beta_{1 \mathrm{C}}$. The E52-3 cell line expressed the $\alpha_{1 \mathrm{E}}$-type Ca channel with the $\alpha_{1 \mathrm{E}-3^{-}} \alpha_{2 \mathrm{~B}} \delta-\beta_{1 \mathrm{~B}}$ subunit composition.

HEK293 cells stably expressing $\mathrm{Ca}^{2+}$-channels were grown in plastic Falcon dishes in DMEM (Life Technologies, Gaithersburg, MD) containing 5\% defined bovine serum (HyClone, Logan, UT) plus penicillin G $(100 \mathrm{U} / \mathrm{ml})$, streptomycin sulfate $(100 \mu \mathrm{g} / \mathrm{ml})$, and geneticin $(500 \mu \mathrm{g} / \mathrm{ml})$. One day before recording, cells were dissociated by gentle trituration with 
a fire-polished Pasteur pipette and replated onto poly-L-lysine-coated glass coverslips.

Preparation of G-protein expression plasmids. cDNAs encoding $\alpha$ subunits of $G_{i 1-3}$ and $G_{o}$ (kindly provided by Randall R. Reed, Johns Hopkins University) were subcloned into the mammalian expression vector pCMV5 (Andersson et al., 1989) and confirmed by DNA sequencing using a modification of the dideoxy-chain termination method (Sequenase 2.0; USB, Cleveland, $\mathrm{OH}$ ). The cDNA $\mathrm{G}_{\mathrm{s} \alpha}$ was similarly subcloned into pCMV6b and confirmed by sequencing (Robishaw et al., 1986). The cDNAs encoding $\mathrm{G}_{13}$ and $\mathrm{G}_{\mathrm{q}}$ in pcDNA3 were obtained from G. Babnigg (University of Chicago). $\kappa$ opioid receptor cDNA in pCMV5 was a kind gift of Graeme Bell (University of Chicago).

Transfection of HEK293 cells. Monolayers of HEK293 cells not exceeding $75 \%$ confluence were dissociated and replated onto poly-L-lysinecoated (Sigma, St. Louis, MO) glass coverslips. Cells were cotransfected with plasmids containing the cDNAs for the $\kappa$ receptor, G-protein, and $\beta$-galactosidase using the standard calcium-phosphate precipitation technique (Ausubel et al., 1993) or transfection kit (Mammalian Transfection Kit; Stratagene, La Jolla, CA).

Analysis of gene and cDNA expression. For patch-clamp experiments, duplicate coverslips were routinely stained for $\beta$-galactosidase expression, with an average transfection efficiency of $40-70 \%$ determined by cell counting. Currents were recorded $48-72 \mathrm{hr}$ after transfection.

The expression of the $\kappa$ receptor was detected using the specific antibody (kindly provided by Robert Elde, University of Minnesota) and $\mathrm{ABC}$ kit (Vector Laboratories, Burlingame, CA).

The expression of the G-protein subunits was evaluated using PCRSouthern blot and Northern blot analysis, as follows. Total RNA was prepared using the $\mathrm{CsCl}$ guanidinium isothiocyanate method (Sambrook et al., 1989). Poly $\left(\mathrm{A}^{+}\right)$RNA was prepared using an oligo-dT-Sepharose column or an mRNA purification kit (Pharmacia, Uppsala, Sweden); 15-20 $\mu \mathrm{g}$ of total RNA or 1-2 $\mu \mathrm{g}$ of poly $\left(\mathrm{A}^{+}\right) \mathrm{RNA}$ was loaded per lane. RNA was transferred to Hybond- $\mathrm{N}^{+}$(Amersham) by overnight blotting. The blots were hybridized using the ${ }^{32} \mathrm{P}$-labeled-specific oligonucleotide probes (internal sequence) for the individual G-protein $\alpha$ subunits as shown below. In some control experiments (not shown), cDNAs for specific G-proteins were ${ }^{32} \mathrm{P}$-labeled by random priming and also used as probes. After hybridization [in the solution containing $20 \%$ formamide, $5 \times$ SSC $(1 \times$ SSC: $150 \mathrm{~mm} \mathrm{NaCl}, 15 \mathrm{~mm}$ sodium citrate $), 2.5 \times$ Denhardt's solution] for $12-20 \mathrm{hr}$, the membranes were rinsed in $2 \times \mathrm{SSC}, 0.1 \%$ SDS for $10 \mathrm{~min}$ at room temperature, washed in $0.5 \times \mathrm{SSC}, 0.1 \% \mathrm{SDS}$ at $42^{\circ} \mathrm{C}$ for 20-40 min, and then exposed to Kodak X-omat film for $12 \mathrm{hr}$.

For PCR-based detection of expression, first-strand cDNA was prepared from total RNA using random primers and Superscript reverse transcriptase (Life Technologies, Grand Island, NY). The following oligonucleotide primer pairs (forward and reverse) were used.

Gi 1 1-Forward: 5'-CTGTGGAAGGACAGCGGTGTG-3'

Reverse: 5'-CAGCAACAGAGAATGTAGTG-3'

Internal: 5'-GCAGTGGGGTAGTAAAAATGCATT-3'

Gi 2 2-Forward: 5'-CCTGTCGGGCGTCATCCGGAG-3'

Reverse: 5'-CCATGCTCCCTGCCTGTTCCC-3'

Internal: 5'-GATGAATCGCATGCATGAGAGC-3'

Gi 3 -Forward: 5'-GATTAAACGTTTATGGCGAG-3'

Reverse: 5'-GCATGACAGGACCAAGGAATG-3'

Internal: 5'-GAGGATGGCATAGTAAAAGCT-3'

Go-Forward: 5'-CACTGAACCATTCTCTGCAG-3'

Reverse: 5'-TTTGGCCTTTGTAAGACACAC-3'

Internal: 5'-CACTCAGCGGCTATGACCAG-3'

Gs-Forward: 5'-GACCAACCGCCTGCAGGAGGC-3'

Reverse: 5'-GGGCATGATTAACAAAGCAACC-3' (bovine)

Reverse: 5'-GGGCATGATTCACACCGCAACC-3' (rat)

Internal: 5'-CACGCAGTTGATCACCCACC-3'

$G q$-Forward: 5'-CTACCCCTGGTTCCAGAACTCC-3'

Reverse: 5'-CACGCTCACAGAGTCCAGGACG-3'

Internal: 5'-GTCGACTAGGTGGGAATACATG-3'

G13-Forward: 5'-CGGGTTTTCAGCAACGTCTCC-3'

Reverse: 5'-TCAGCAGCTGTCAGCCACA-3'

Internal: 5'-CTCTTAAGCAGTGGGGGTCC-3'

The PCR was used under the following conditions: $45 \mathrm{sec}$ at $94^{\circ} \mathrm{C}, 1 \mathrm{~min}$ at $55^{\circ} \mathrm{C}$, and $1 \mathrm{~min}$ at $72^{\circ} \mathrm{C}$ for 30 cycles, followed by $10 \mathrm{~min}$ at $72^{\circ} \mathrm{C}$. An aliquot of the PCR sample was analyzed by electrophoresis in $1 \%$ agarose. DNAs were transferred to Hybond- $\mathrm{N}^{+}$(Amersham) and then hybridized with the specific oligonucleotide probe (internal) for each G-protein $\alpha$ subunit shown above, using the conditions described.

Whole-cell patch clamp. The tight-seal whole-cell configuration of the patch-clamp technique (Hamill et al., 1981) was used to record $\mathrm{Ca}$ currents. Recordings were made at room temperature $\left(21-24^{\circ} \mathrm{C}\right)$. Currents were recorded using an Axopatch 1D (Axon Instruments, Foster City, CA) amplifier, filtered at $2 \mathrm{kHz}$ by the built-in filter of the amplifier, and stored on the computer. Capacitative transients were canceled at 10 $\mathrm{MHz}$, and their values were obtained directly, together with the seriesresistance values from the settings of the Axopatch $1 \mathrm{D}$ amplifier. Seriesresistance compensation between 40 and $80 \%$ was applied. Leak corrections were performed using a $\mathrm{P} / \mathrm{N}$ protocol. Command pulses were delivered at $20 \mathrm{sec}$ intervals. Soft, soda-lime capillary glass was used to make patch pipettes, which were coated with Sylgard (Dow Corning, Midland, MI) and had resistances of 1.8-3.5 $\mathrm{M} \Omega$ when filled with internal solution. Extracellular buffer solution for whole-cell voltage-clamp experiments was composed of (in $\mathrm{mM}$ ): 160 tetraethylammonium chloride, 5 $\mathrm{CaCl}, 1 \mathrm{MgCl}_{2}, 10$ HEPES, 10 glucose; $\mathrm{pH}$ was adjusted to 7.4 with TEAOH. The standard internal solution consisted of (in mM): $100 \mathrm{CsCl}$, $37 \mathrm{CsOH}, 1 \mathrm{MgCl}_{2}$, 10 BAPTA, 10 HEPES, 3.6 MgATP, $1 \mathrm{GTP}$, and 14 $\mathrm{Tris}_{2} \mathrm{CP}$, and $50 \mathrm{U} / \mathrm{ml}^{-1} \mathrm{CPK}$. The $\mathrm{pH}$ was adjusted to 7.3 with $\mathrm{CsOH}$. The osmolarity of the pipette solution was $300 \mathrm{mOsm} / \mathrm{l}$, and the osmolarity of the extracellular solution was between 315 and $323 \mathrm{mOsm} / \mathrm{l}$. GTP was replaced by GTP- $\gamma$-S or by GDP $\beta$ S in the double-pulse and tail-current experiments.

Stock solutions of U69593 (RBI, Natick, MA) and nor-BNI (RBI) were prepared in ethanol and stored at $-20^{\circ} \mathrm{C}$. $\left[\mathrm{D}-\mathrm{Trp}^{8}\right]$ somatostatin (SOM) stock solutions (Bachem, Belmont, CA) were kept at $-80^{\circ} \mathrm{C}$. Stock solutions of PTX $(100 \mu \mathrm{g} / \mathrm{ml}$; RBI) were prepared in water and stored at $4^{\circ} \mathrm{C}$. Cells were treated with PTX at a final concentration of $200 \mathrm{ng} / \mathrm{ml}$ overnight.

\section{RESULTS \\ Effects of GTP analogs}

We examined the regulation of $\alpha_{1 \mathrm{~B}}$ - and $\alpha_{1 \mathrm{E}}$-based Ca channels stably expressed in HEK293 cells. Ca channels in these cells also contained stably expressed $\alpha_{2} / \delta$ and $\beta_{1 \text { B }}$ subunits (Williams et al., 1992; Bleakman et al., 1995). It has been shown that the presence of these ancillary subunits is essential for $\mathrm{Ca}$ channels to be expressed efficiently and display all of their normal properties (Williams et al., 1992; Bleakman et al., 1995). Ca currents could be elicited in these cells by step depolarizations to different potentials. Cells expressing $\alpha_{1 \mathrm{~B}}$ produced $\mathrm{Ca}$ currents that had properties of typical $\mathrm{N}$ currents (Bleakman et al., 1995). Cells expressing $\alpha_{1 \mathrm{E}}$ produced currents whose properties we have described previously and which are similar to currents described in the literature as "R" type (Williams et al., 1994; Wheeler et al., 1995).

We wished to compare the regulation of $\alpha_{1 \mathrm{~B}}$ and $\alpha_{1 \mathrm{E}}$ channels by G-proteins. To do this, we began by examining the effect of activating the G-proteins normally found in HEK293 cells directly, using the nonhydrolyzable analog of GTP, GTP- $\gamma$-S. One interesting phenomenon was apparent immediately. Normally there was a marked increase in the amplitude of the Ca current in $\alpha_{1 \mathrm{~B}}$-expressing cells in the period after the pipette broke into the cell (Fig. 1A). This "run-up" of the current was not apparent in GTP- $\gamma$-S-containing cells (Fig. 1B). One of the hallmarks of rapid "membrane-delimited" $\mathrm{N}$-current inhibition is that it can be relieved by a depolarizing prepulse to high voltages (Bean, 1989; Hille, 1994). If the current observed during GTP- $\gamma$-S perfusion represents an inhibited current, then a depolarizing prepulse should increase its amplitude. We therefore used a voltage-clamp protocol that consisted of two test pulses with or without a strong intervening depolarization to $+80 \mathrm{mV}$ (Fig. 1C,D). The ratio of current integrals (P2/P1) was plotted as a function of time (Fig. $2 A-C$ ). The ratio $\mathrm{P} 2 / \mathrm{P} 1$ became larger after the prepulse (Fig. $2 A$ ). Figure $2 A$ shows that the maximum GTP- $\gamma$-S effect developed $\sim 4$ min after establishing whole-cell recording conditions. At this time, there was no difference in P2/P1 ratios with GDP $\beta$ S in the pipette (Fig. $2 B$ ), consistent with the "inhibitory" action of 
A

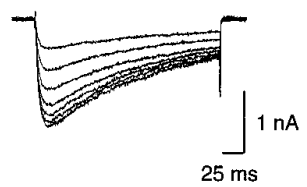

B

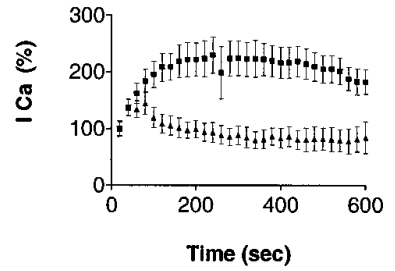

C

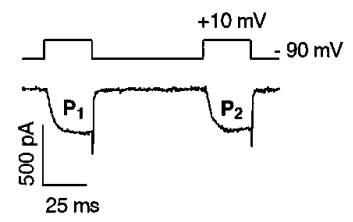

$E$

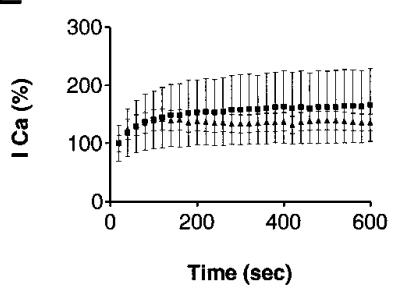

D

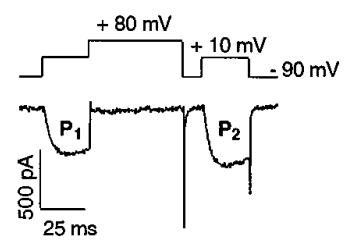

$\mathrm{F}$

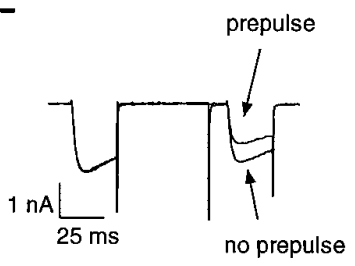

Figure 1. Ca currents in HEK293 cells expressing the $\alpha_{1 \mathrm{~B}}$ and $\alpha_{1 \mathrm{E}} \mathrm{Ca}$ channel subunits. $A$, Run-up with intracellular GTP using Ca $(5 \mathrm{~mm})$ as the charge carrier in HEK293 cells expressing the $\alpha_{1 \mathrm{~B}} \mathrm{Ca}$ channel subunit. Currents were evoked from a holding potential of $-90 \mathrm{mV}$ by $200 \mathrm{msec}$ depolarizing pulses to $+10 \mathrm{mV}$ every $20 \mathrm{sec}$. $B$, Average normalized current with $1 \mathrm{~mm} \mathrm{GTP}(\mathbf{\square})$ or $0.3 \mathrm{~mm} \mathrm{GTP}-\gamma-\mathrm{S}(\mathbf{\Delta})$ in the patch pipette. The run-up of currents from individual experiments was normalized with respect to the first peak current obtained. The normalized values were then averaged, and the mean \pm SEM was plotted (1 mM GTP, $n=11 ; 0.3$ mм GTP- $\gamma$-S, $n=6$ ). $C$, $D$, Relief of GTP- $\gamma$-S-induced inhibition of $\alpha_{1 \text { в }}$ $\mathrm{Ca}$ currents by an intervening prepulse depolarization. Ca currents were evoked using a double-pulse protocol without $(C$, lower trace $)$ or with $(D$, lower trace $)$ a depolarizing prepulse using GTP- $\gamma-\mathrm{S}(0.3 \mathrm{mM})$ in the patch pipette. The intervening depolarization increased the current amplitude during the second pulse $(D$, lower trace). Upper lines in $C$ and $D$ are the voltage templates $(\mathrm{HP}=-90 \mathrm{mV} ; \mathrm{TP}=+10 \mathrm{mV}$; TP duration $=25$ msec; prepulse depolarization potential $=+80 \mathrm{mV}$; duration $=50 \mathrm{msec}$ ). P1 and P2 denote the current integrals during the first and second test pulses and are used as such in Figure 2. E, Characteristics of Ca current run-up in cells expressing $\alpha_{1 \mathrm{E}}$ subunit. Plot of averaged Ca current amplitude (mean \pm SEM) in the presence of GTP- $\gamma$-S $(\boldsymbol{\Lambda}, 0.3 \mathrm{mM} ; n=15)$ or GTP $(\mathbf{\square}, 1 \mathrm{~mm} ; n=6)$. Calculations as in $B$. F, Superimposed $\mathrm{Ca}^{2+}$ current traces evoked by the double-pulse voltage protocol with or without a depolarizing prepulse (1 mM GTP in the patch pipette). The Ca current following the prepulse depolarization was actually smaller than without it in the cell line expressing $\alpha_{1 \mathrm{E}}$ subunit.

GDP $\beta$ S on G-protein function. The small difference in the P2/P1 ratios observed using $1 \mathrm{~mm}$ GTP in the patch pipette was presumably attributable to a small degree of basal G-protein activation under these conditions (Fig. 2C). Interestingly, the degree of "run-up" in $\alpha_{1 \mathrm{E}}$-expressing cells was less marked than in $\alpha_{1 \mathrm{~B}^{-}}$ expressing cells. Although there was a trend suggesting that this small degree of run-up was also suppressed by GTP- $\gamma$-S, this was not significant (Fig. 1E). Furthermore, in these cells, the current evoked by a test pulse after a depolarization also was actually smaller than without the prepulse (Fig. $1 F$ ). This was presumably attributable to differences in the extent of voltage-dependent inactivation between the two types of Ca channels (Williams et al.,

1994; Bleakman et al., 1995). Consistent with this finding, the "R"-type current in cerebellar granule neurons also displayed very pronounced voltage-dependent inactivation (Zhang et al., 1993). Thus, for $\alpha_{1 \mathrm{E}}$ currents, the value of the $\mathrm{P} 2 / \mathrm{P} 1$ ratio after the prepulse fell below that seen without the prepulse (Fig. $2 D-F$ ). We therefore normalized the data by subtracting out the degree of voltage-dependent inactivation. This was obtained from cells perfused with GDP $\beta$ S, in which we assumed that no G-proteininduced inhibition would be present. After this transformation, the data obtained with GTP or GTP- $\gamma$-S in the pipette followed a trend similar to that obtained with $\alpha_{1 \mathrm{~B}}$-based channels (Fig. $2 D-F$, red data sets). Comparison of the data in Figure $2 A-C$ with that in $D-F$, however, suggests that although there is some G-proteinmediated inhibition of $\alpha_{1 \mathrm{E}}$ channels, this is 7- to 10-fold less than that obtained with $\alpha_{1 \mathrm{~B}}$ channels. This suggests that there is a considerable difference in the ability of G-proteins to regulate $\alpha_{1 \mathrm{~B}^{-}}$and $\alpha_{1 \mathrm{E}^{-}}$based Ca channels directly.

\section{Receptor regulation of Ca currents}

The results presented above demonstrate that direct activation of G-proteins in these cell lines produces strong inhibition of $\alpha_{1 \mathrm{~B}}$ but not $\alpha_{1 \mathrm{E}}$ channels. G-proteins are normally activated by "serpentine" receptors, and this can lead to inhibition of Ca currents in neurons. We attempted to reconstitute receptor regulation of $\mathrm{Ca}$ channels in HEK293 cells using endogenous and exogenous receptors. There are several examples in the literature of the regulation of $\mathrm{Ca}$ currents by somatostatin receptors (Ikeda and Schofield, 1989; Golard and Siegelbaum, 1993; Fujii et al., 1994; Hille, 1994), and endogenous somatostatin receptors have been reported to exist in HEK293 cells (Law et al., 1993). We found that activation of these receptors with the somatostatin analog SOM produced substantial inhibition of the Ca currents in $\alpha_{1 \mathrm{~B}^{-}}$ expressing cells (Fig. $3 A, D$ ). Little or no inhibition, however, was observed in cells expressing $\alpha_{1 \mathrm{E}}$ channels (Fig. $3 C, D$ ). Inhibition of the $\alpha_{1 \mathrm{~B}}$ Ca current by SOM was repeatable, exhibiting modest desensitization $(38.5 \pm 5.5 \%$ inhibition on first application, $26.2 \pm$ $3.8 \%$ inhibition on second; $n=6$ ). Furthermore, inhibition of $\alpha_{1 \mathrm{~B}}$ currents was blocked by pretreatment of cells with PTX (Fig. 3D) and was relieved partially by a depolarizing prepulse (Fig. $3 B$ ). We also observed that SOM was equally effective in inhibiting the $\mathrm{Ca}$ current in a second $\alpha_{1 \mathrm{~B}}$-expressing cell line that differed in the type of $\beta$ subunit $\left(\beta_{1 \mathrm{C}}\right.$ ) expressed (Fig. $3 D$ ).

Activation of $\kappa$ opioid receptors in some neurons has also been shown to produce inhibition of Ca currents (Lipscombe et al., 1989; Rhim and Miller, 1994). In contrast to the effects of SOM, however, addition of a selective agonist for the $\kappa$ opioid receptor U69593 produced no inhibition of Ca currents in either the $\alpha_{1 \mathrm{~B}}$ or $\alpha_{1 \mathrm{E}}$ cell line. This was consistent with the lack of $\kappa$ opioid receptors in HEK293 cells as indicated by immunostaining or Northern blot analysis (data not shown). We therefore transiently transfected the $\kappa$ opioid receptor into both $\alpha_{1 \mathrm{~B}^{-}}$and $\alpha_{1 \mathrm{E}^{-}}$ expressing cell lines. Northern blots and immunostaining indicated similar degrees of transfection into the two cell lines (not shown). After transfection, U69593 robustly inhibited the Ca current in $\alpha_{1 \mathrm{~B}}$ but not in $\alpha_{1 \mathrm{E}}$-containing cells (Fig. 4). Inhibition by SOM was retained in these cells (data not shown). U69593induced inhibition was blocked by nor-BNI, a specific inhibitor of $\kappa$ opioid receptors (Fig. 4). Inhibition produced by U69593 was also partially voltage-dependent and inhibited by PTX treatment (Figs. 4, 5).

It seemed possible that our inability to observe strong G-protein regulation of $\alpha_{1 \mathrm{E}}$ currents was attributable to the fact 
A

$\alpha_{1 B} / 0.3 \mathrm{mM}$ GTPYs

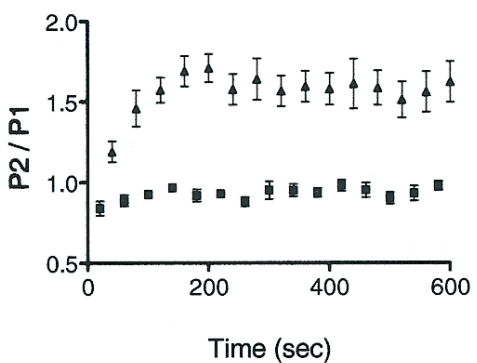

B

$\alpha_{1 B} / 0.3 \mathrm{mM}$ GDPBS

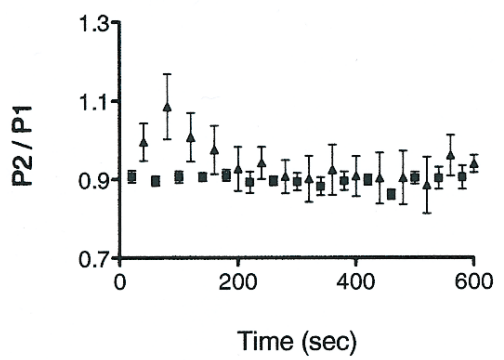

C $\alpha_{1 \mathrm{~B}} / 1 \mathrm{mMGTP}$

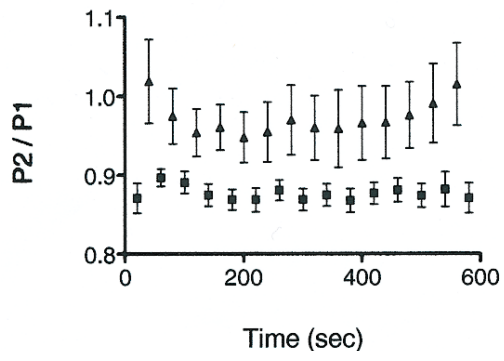

D
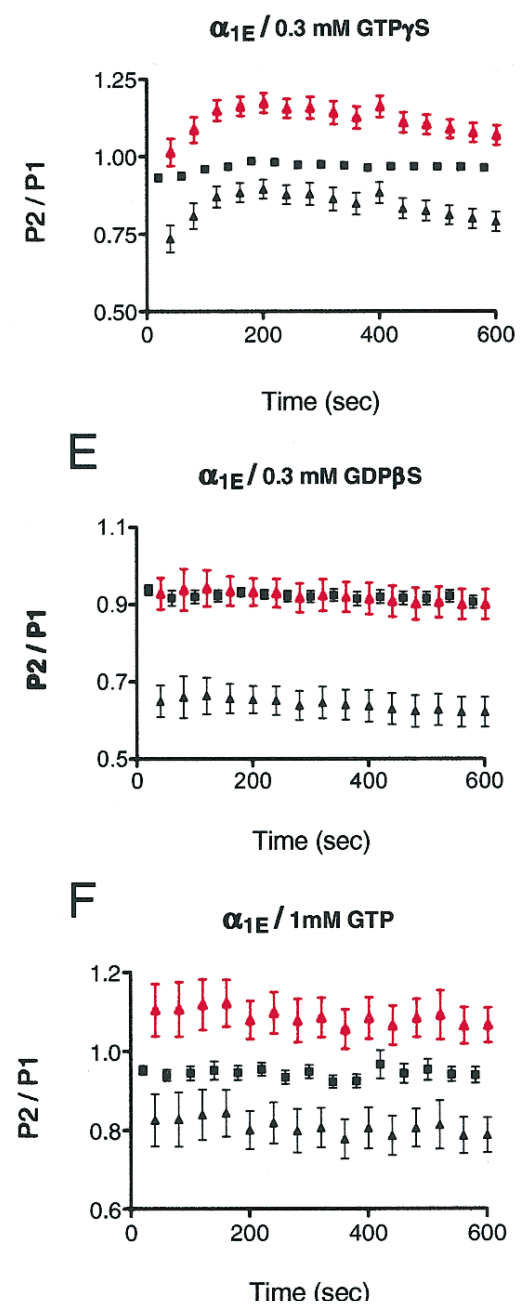

that HEK293 cells lacked a particular G-protein that was required for regulation of $\alpha_{1 \mathrm{E}}$. We observed, however, that under normal conditions the cells expressed mRNAs for many different G-proteins, including representative members of all of the four major families $\left(\alpha_{\mathrm{i} / \mathrm{o}}, \alpha_{\mathrm{s}}, \alpha_{\mathrm{q}}, \alpha_{13}\right)$ (data not shown). Nevertheless, it was still possible that the actual quantities of some of these might be limiting. We therefore overexpressed several different G-protein $\alpha$ subunits with and without the $\kappa$ opioid receptor and examined the ability of U69593 or SOM to inhibit Ca currents in the two cell lines. Overexpression of each of the G-protein $\alpha$ subunits was confirmed by Northern blot analysis. Overexpression of some of the G-protein $\alpha$ subunits actually slightly enhanced the ability of U69593 to inhibit Ca currents in $\alpha_{1 \mathrm{~B}}$-expressing cells (Figs. $5 B-D, 6 A$ ), although the effects of SOM were not altered (Fig. $6 B$ ). In cells overexpressing G-protein $\alpha$ subunits, the effects observed were still blocked by PTX (Figs. 4, 6A) and were still partially voltage-dependent (Fig. $5 D$ ). On the other hand, no substantial effect of U69593 (Fig. 6C) on $\alpha_{1 \mathrm{E}}$ currents was observed, even in cells in which we overexpressed different G-protein $\alpha$ subunits.

\section{DISCUSSION}

We have used an HEK293 cell expression system to make some initial attempts at understanding the G-protein regulation of $\mathrm{Ca}$ channels. The two types of Ca channels investigated in the present series of experiments, $\alpha_{1 \mathrm{~B}}$ and $\alpha_{1 \mathrm{E}}$, are both members of the family of nondihydropyridine-sensitive channels generally found in neurons and neuroendocrine cells. These $\alpha$ subunits exhibit a high degree of homology with each other; they are $\sim 80 \%$ homologous in those regions that have been suggested as compromising the 24 transmembrane helices. The degree of homology between the two types of channels falls to $\sim 40 \%$, however, in nontransmembrane-spanning regions such as the intracellular loop connecting domains 3 and 4 and the intracellular C-terminal extension (Soong et al., 1993; Schneider et al., 1994; Williams et al., 1994; Wheeler et al., 1995). Considering the high degree of overall homology between $\alpha_{1 \mathrm{~B}}$ and $\alpha_{1 \mathrm{E}}$ and of these proteins with $\alpha_{1 \mathrm{~A}}$, it is of considerable interest to note the large difference in the ability of the two channel types to be regulated by G-proteins. The regulation of $\mathrm{N}$ channels that we have observed in HEK293 cells closely resembles that frequently described in neurons (Hille, 1994). Little is known as yet, however, about the normal properties and functions of the $\mathrm{Ca}$ channels that are formed by expression of $\alpha_{1 \mathrm{E}}$, although the protein is widely expressed on the soma and dendrites of neurons throughout the brain (Williams et al., 1994; Volsen et al., 1995; Yokoyama et al., 1995). The experiments reported here suggest that direct G-protein regulation of 


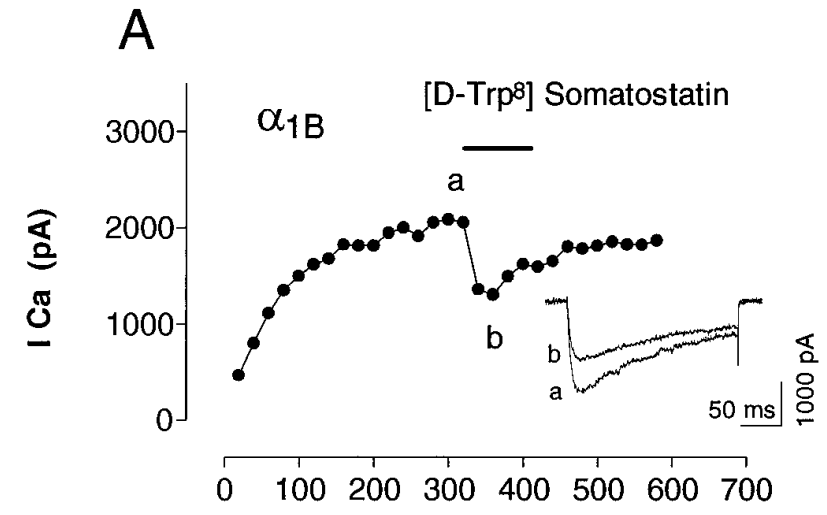

Time (sec)

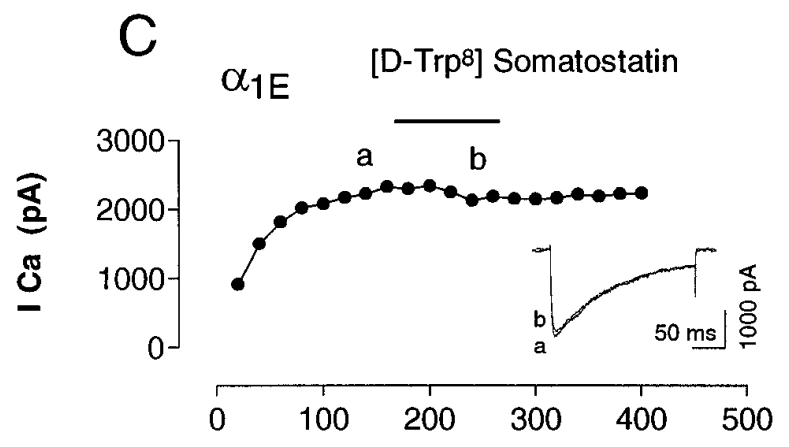

B

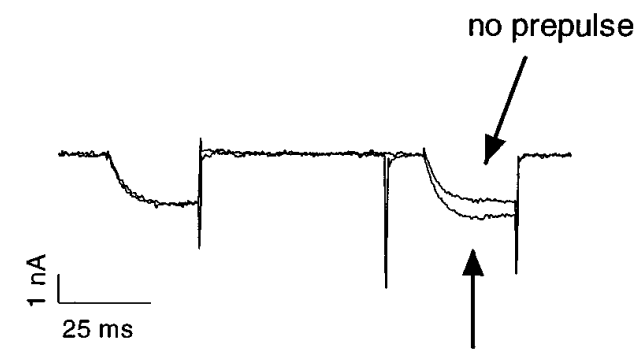

with prepulse

\section{Time (sec)}

Figure 3. Effect of SOM on $\alpha_{1 \mathrm{~B}}$-type and $\alpha_{1 \mathrm{E}}$ Ca currents. $A$, Plot of $\alpha_{1 \mathrm{~B}}$-type Ca current versus time showing a typical SOM (300 nM) response. Cell was depolarized from $-90 \mathrm{HP}$ to $+10 \mathrm{TP}$ every $20 \mathrm{sec}$. Inset shows Ca currents recorded before and during SOM application. $B$ shows $\alpha_{1 \mathrm{~B}}$-type Ca currents evoked by the double-pulse protocol in the presence of SOM (300 nM). Decreased inhibition can be seen after the prepulse. $C$, Plot of $\alpha_{1 \mathrm{E}}$-type Ca current versus time: SOM had little or no effect on the Ca current. $D$, Average responses (mean \pm SEM) to SOM (300 nM) application. The number in parentheses represents the number of experiments.

these channels may be quite minimal. It should be noted that in our studies we found that G-proteins representative of all of the four major families were represented in HEK293 cells, and at least one member of each of these families was also overexpressed

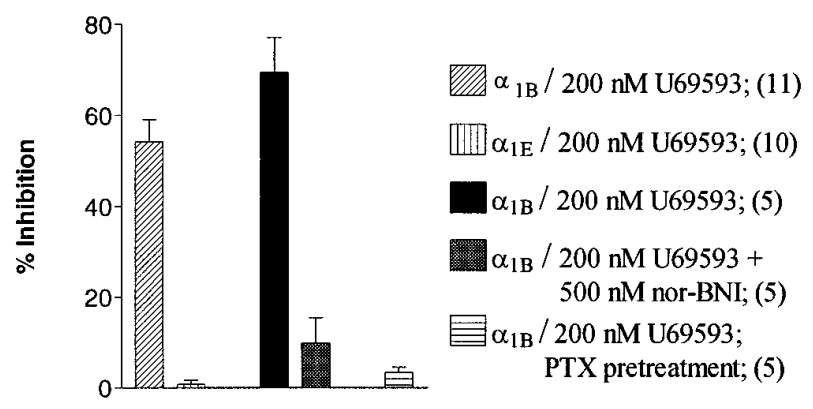

Figure 4. Effects of the $\kappa$ receptor-selective agonist U69593 on $\kappa$ receptor-transfected HEK293 cells expressing $\alpha_{1 \mathrm{~B}}$ and $\alpha_{1 \mathrm{E}}$ Ca channels. Average responses (mean $\pm \mathrm{SEM}$ ) to $\mathrm{U} 69593(200 \mathrm{nM}) ; n=$ number of cells showing response to $\kappa$ receptor agonist application (left to right, bars 1,3 , and 4) or all cells tested (bars 2 and 5). In experiments in which the blocking effect of nor-BNI was examined, cells were also transfected with the $\alpha$ subunit of $\mathrm{G}_{\mathrm{o}}$ (see below). In the experiments examining the blocking effect of PTX (200 ng/ml overnight), cells were also transfected with the $\alpha$-subunit of $\mathrm{G}_{\mathrm{i} 2}$ (see text). in our experiments. Thus, although it remains possible that $\alpha_{1 \mathrm{E}}$ channels are normally regulated through an exceedingly restricted direct G-protein pathway that we have missed, this seems unlikely. It should be noted in this regard that although $\mathrm{N}$ channel inhibition tends to be mediated by PTX-sensitive G-proteins, there are several examples of non-PTX-sensitive G-proteins also producing this type of direct, membrane-delimited inhibition (Hille, 1994; Zhu and Ikeda, 1994). This implies that for $\mathrm{N}$ channels, many types of G-protein $\alpha$ subunits may be able to interact with the channel. Another interpretation of these observations would be that it is actually the $\beta / \gamma$ subunits that produce the inhibition and that these may be released from various receptor-activated G-protein heterotrimers (Ikeda, 1996; Herlitze et al., 1996). Whichever mechanism is involved, it seems unlikely that any G-protein regulation of highly homologous $\alpha_{1 \mathrm{E}}$ channels would be highly selective. In our experiments, we have also tried to produce regulation of $\alpha_{1 \mathrm{E}}$ channels in several different ways. Thus, introduction of GTP- $\gamma$-S into cells would activate the entire complement of HEK293 cell G-proteins (Zhou et al., 1995; Zong et al., 1995). Furthermore, we also used somatostatin receptors (Law et al., 1993; Shapiro and Hille, 1993; Reisine and Bell, 1995) and $\kappa$ opioid receptors (Shen and Crain, 1994; Avidor-Reiss et al., 1995; Ikeda et al., 1995; Lai et al., 1995; Tallent et al., 1995), both of which can activate a wide variety of G-proteins. Interestingly, all 
A $\quad \alpha_{18} / \kappa$
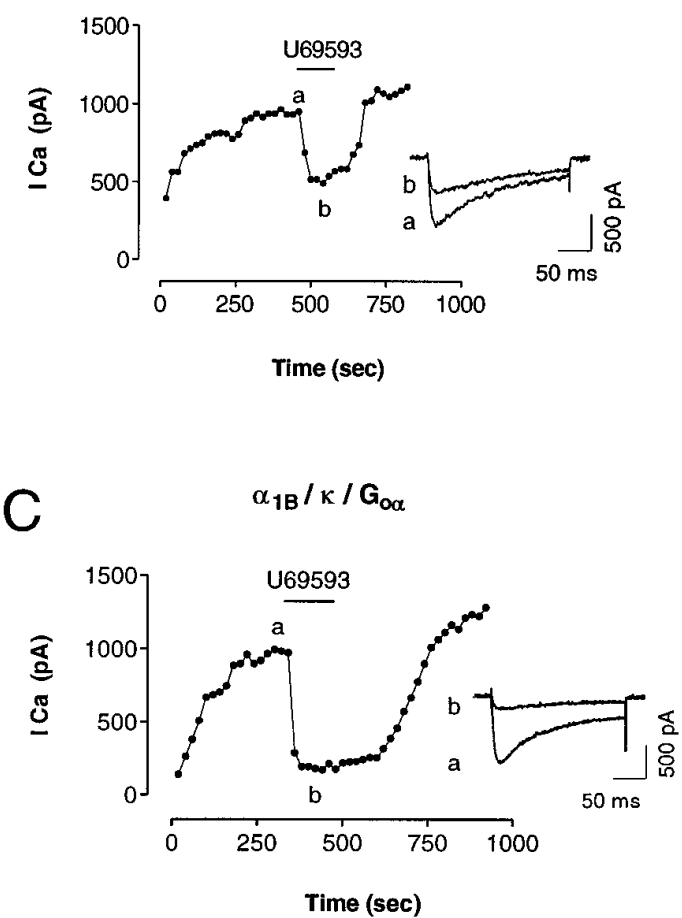

B $\alpha_{1 \mathrm{~B}} / \mathrm{K} / \mathrm{G}_{\mathrm{i \alpha 1}}$

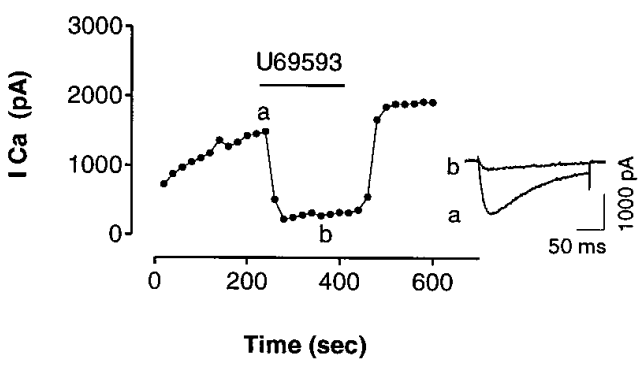

D $\quad \alpha_{18} / \kappa / G_{\alpha 3}$

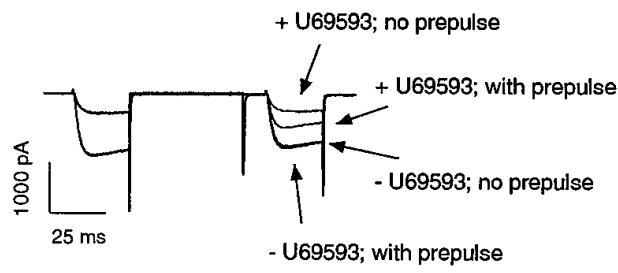

Figure 5. Effect of G-protein $\alpha$ subunit overexpression on Ca current inhibition by $\kappa$ receptor activation in cells expressing $\alpha_{1 \mathrm{~B}}$ Ca channels. $A-C$, Plots of Ca current versus time. Insets show Ca current traces at the points indicated before and during the application of the $\kappa$ receptor agonist U69593 (200 nM). HEK293 cells were transfected with only the $\kappa$ receptor $(A)$, $\kappa$ receptor $+\mathrm{G}_{\mathrm{i} \alpha 1}(B)$, $\kappa$ receptor $+\mathrm{G}_{\mathrm{o} \alpha}(C)$, and $\kappa$ receptor $+\mathrm{G}_{\mathrm{i} \alpha 3}(D)$. $D$, Superimposed control and inhibited (U69593; $200 \mathrm{nM}$ ) Ca current traces from a cell expressing the $\alpha_{1 \mathrm{~B}} \mathrm{Ca}$ channel, $\kappa$ receptor, and $\mathrm{G}_{\mathrm{i} \alpha 3}$. The U69593 inhibition was partially relieved by a prepulse depolarization (see Fig. 2).

of these manipulations produced robust inhibition of $\alpha_{1 \mathrm{~B}}$ channels, which had the same ancillary subunit composition as the $\alpha_{1 \mathrm{E}}$ channels. We conclude that it is unlikely that we failed to observe regulation of $\alpha_{1 \mathrm{E}}$ channels because of the fact that we failed to express the correct components for observing such regulation, if it did indeed exist.

The characteristics of inhibition of $\alpha_{1 \mathrm{~B}}$ channels observed in the present experiments are similar in many respects to those reported previously. For example, the inhibition displayed both voltage-dependent and -independent components (Bean, 1989; Hille, 1994; Diverse-Pierluissi and Dunlap, 1995; DiversePierluissi et al., 1995). Whether this is attributable to activation of more than one G-protein-linked pathway, thereby producing more than one effect on the channels as suggested in the literature, is difficult to assess (Diverse-Pierluissi and Dunlap, 1995; Diverse-Pierluissi et al., 1995). Thus, HEK293 cells normally contained various G-proteins, even before the introduction of more of these molecules by transfection. Furthermore, both somatostatin and $\kappa$ opioid receptors potentially can activate several of these G-proteins. The results, however, are also consistent with a single process. The effect of the depolarizing prepulse is assumed to lower the affinity of the interaction between the G-protein subunit(s) and the channel that allows unbinding (Boland and Bean, 1993). It is possible that rebinding of the G-protein might occur with a time course that is beyond the resolution of this study.

The present observations set some limitations on the localization of G-protein-binding to the $\alpha_{1 \mathrm{~B}}$ channel. Thus, there is a high degree of sequence identity between $\alpha_{1 \mathrm{~B}}$ and $\alpha_{1 \mathrm{E}}$ in their 24 putative membrane-spanning domains (Soong et al., 1993; Schneider et al., 1994; Williams et al., 1994; Wheeler et al., 1995). On the other hand, other areas exhibit less homology. This is particularly true of the large intracellular loop between domains 2 and 3 and the $\mathrm{N}$ and $\mathrm{C}$ termini. Furthermore, the smaller intracellular loop between domains 1 and 2 also shows considerable divergence. It is interesting to note that this small loop is the site of interaction between the Ca channel $\alpha$ subunit and the small $\beta$ subunit (Pragnell et al., 1994). Some studies have suggested that $\mathrm{Ca}$ channel $\beta$ subunits and $\mathrm{G}$-protein subunits may compete for a binding site on the Ca channel $\alpha_{1}$ subunit, although it is not clear whether such an interaction is competitive or allosteric (Berrow et al., 1995; Campbell et al., 1995b; Roche et al., 1995). It has been suggested further that the $\alpha$ subunits of $\mathrm{Ca}$ channels may possess GAP activity (Campbell et al., 1995a) and that the Ca channel $\alpha$ and $\beta$ subunits cooperate in enhancing the GTPase activity of the G-protein $\alpha$ subunit. Such observations are interesting in light of recent studies showing that G-protein $\alpha$ and $\beta / \gamma$ subunits both bind to GIRK-1, one of the G-protein-regulated K channels (Huang et al., 1995). These studies also suggested that GIRK-1 may also possess GAP activity (Slesinger et al., 1995). It is possible that a similar arrangement also applies to $\mathrm{Ca}$ channels. Resolution of this problem will require elucidation of precisely which G-protein subunits bind to and regulate $\mathrm{Ca}$ channels. 
A
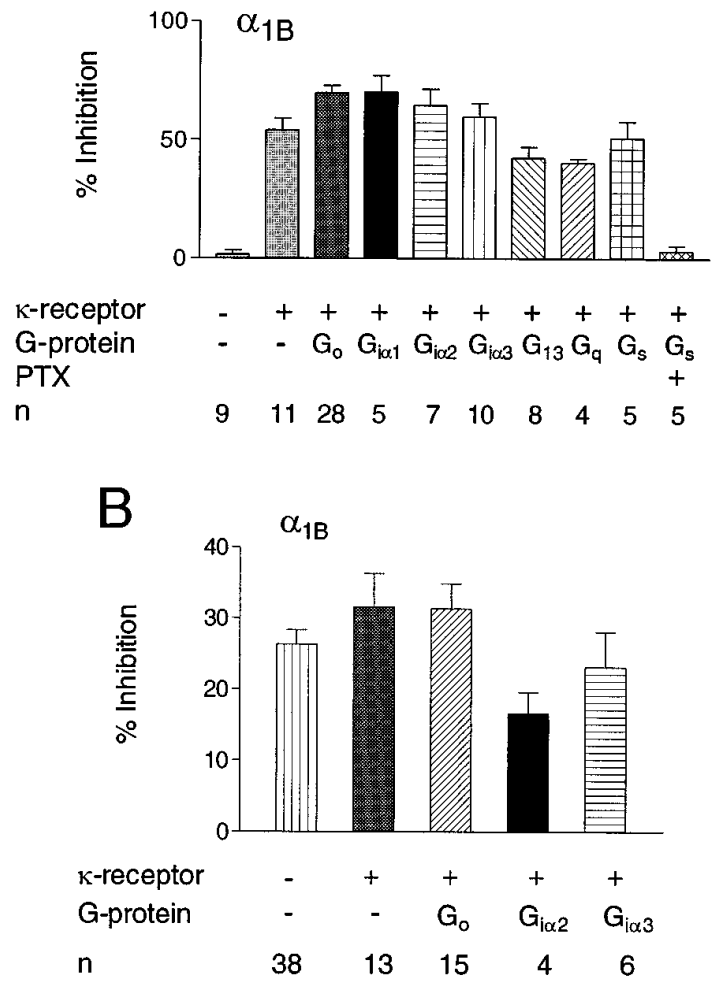

Q

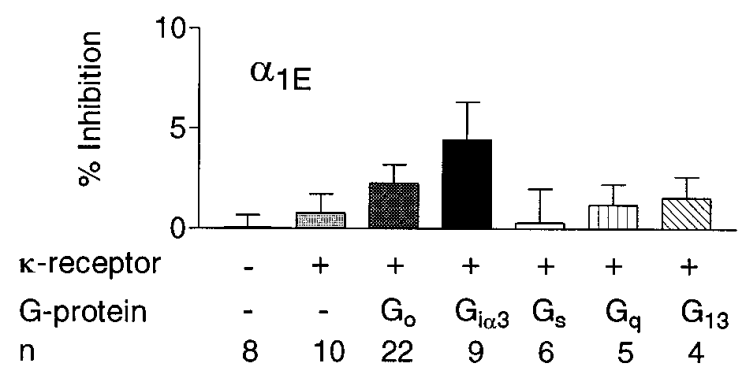

Figure 6. $A$, Average inhibition (mean \pm SEM) of $\alpha_{1 \mathrm{~B}}$ Ca currents by U69593 (200 nM) in HEK293 cells expressing $\alpha_{1 \mathrm{~B}}$ Ca channels, different G-protein $\alpha$ subunits, and the $\kappa$ opioid receptor. $n$ denotes the number of cells showing agonist responses, except the first and last bars, where all of the responses were averaged. $B$, Inhibitory effects (mean \pm SEM) of SOM (300 nM) in HEK293 cells expressing $\alpha_{1 \mathrm{~B}}$ Ca channels, $\kappa$ receptors, and various G-protein $\alpha$ subunits. $n$ denotes the number of responsive cells. $C$, Average inhibition (mean \pm SEM) of the Ca current by U69593 (200 nM) in HEK293 cells expressing $\alpha_{1 \mathrm{E}}$ Ca channels, $\kappa$ receptors, and different G-protein $\alpha$ subunits. $n=$ total number of cells.

\section{REFERENCES}

Andersson S, Davis DL, Dahlback H, Jornvall H, Russell DW (1989) Cloning, structure and expression of the mitochondrial cytochrome P-450 sterol 25-hydroxylase, a bile acid biosynthetic enzyme. J Biol Chem 264:8222-8229.

Ausubel FM, Brent R, Kingston RE, Moore DD, Seidman JG, Smith JA, Struhl K (1993) Transfection of DNA into eukaryotic cells. In: Current protocols in molecular biology, pp 9.1.1-9.1.7. New York: Wiley.

Avidor-Reiss T, Zippel R, Levy R, Saya D, Ezra V, Barg J, MatusLeibovitch N, Vogel Z (1995) $\kappa$-opioid receptor transfected cell lines: modulation of adenylyl cyclase activity following acute and chronic opioid treatment. FEBS Lett 361:70-74.
Bean BP (1989) Neurotransmitter inhibition of neuronal calcium channels by changes in channel voltage dependence. Nature 340:153-156.

Berrow NS, Campbell V, Fitzgerald EM, Brickley K, Dolphin AC (1995) Antisense depletion of $\beta$ subunits modulates the biophysical and pharmacological properties of neuronal calcium channels. J Physiol (Lond) 482:481-491.

Bleakman D, Bowman D, Bath CP, Brust PF, Johnson EC, Deal CR, Miller RJ, Ellis SB, Harpold MM, Hans M, Grantham CJ (1995) Characteristics of a human $\mathrm{N}$ type calcium channel expressed in HEK293 cells. Neuropharmacology 34:753-765.

Boland LM, Bean BP (1993) Modulation of N type calcium channels in bullfrog sympathetic neurons by luteinizing hormone releasing hormone, kinetics and voltage dependence. J Neurosci 13:516-533.

Campbell V, Berrow N, Brickley K, Page K, Wade R, Dolphin AC (1995a) Voltage dependent calcium channel $\beta$ subunits in combination with $\alpha_{1}$ subunits have a GTPase activating effect to promote the hydrolysis of GTP by $\mathrm{G}_{\mathrm{ao}}$ in rat frontal cortex. FEBS Lett 370:135-140.

Campbell V, Berrow EM, Fitzgerald EM, Brickley K, Dolphin AC (1995b) Inhibition of the interaction of G-protein $G_{o}$ with calcium channels by the calcium channel $\beta$ subunit in rat neurons. J Physiol (Lond) 485:365-372.

Diverse-Pierluissi M, Dunlap K (1995) Interaction of convergent pathways that inhibit $\mathrm{N}$ type calcium currents in sensory neurons. Neuroscience 65:477-483.

Diverse-Pierluissi M, Goldsmith PK, Dunlap K (1995) Transmitter mediated inhibition of $\mathrm{N}$ type calcium channels in sensory neurons involves multiple GTP binding proteins and subunits. Neuron 14:191-200.

Dolphin AC (1995) Voltage dependent calcium channels and their modulation by neurotransmitters and G-proteins. Exp Physiol 80:1-36.

Ewald DA, Pang IH, Sternweis PC, Miller RJ (1989) Differential G protein-mediated coupling of neurotransmitter receptors to $\mathrm{Ca}^{2+}$ channels in rat dorsal root ganglion neurons in vitro. Neuron 2:1185-1193.

Fujii Y, Gonoi T, Yamada T, Chihara K, Inagaki N, Seino S (1994) Somatostatin receptor subtype SSTR2 mediates the inhibition of high voltage activated calcium channels by somatostatin and its analogue SMS 201-995. FEBS Lett 355:117-120.

Golard A, Siegelbaum SA (1993) Kinetic basis for the voltage-dependent inhibition of N-type calcium current by somatostatin and norepinephrine in chick sympathetic neurons. J Neurosci 13:3884-3894.

Hamill OP, Marty A, Neher E, Sakmann B, Sigworth FJ (1981) Improved patch-clamp techniques for high resolution current recording from cells and cell-free membrane patches. Pflügers Arch 391:85-100.

Herlitze S, Garcia DE, Mackie K, Hille B, Scheuer T, Catterall WA (1996) Modulation of $\mathrm{Ca}^{2+}$ channels by G-protein $\beta \gamma$ subunits. Nature 380:258-262.

Hille B (1994) Modulation of ion channels by G-protein coupled receptors. Trends Neurosci 17:531-535.

Huang CL, Slesinger PA, Casey PJ, Jan YN, Jan LY (1995) Evidence that direct binding of G $\beta \gamma$ to the GIRK-1 G-protein gated inwardly rectifying $\mathrm{K}$ channel is important for channel activation. Neuron 15:1133-1143.

Ikeda SR (1996) Voltage-dependent modulation of N-type calcium channels by G-protein $\beta \gamma$ subunits. Nature 380:255-258.

Ikeda SR, Schofield GG (1989) Somatostatin blocks a calcium current in rat sympathetic neurons. J Physiol (Lond) 409:221-240.

Ikeda K, Kobayashi T, Ichikawa T, Usui H, Kumanishi T (1995) Functional couplings of the $\delta$ and the $\kappa$ opioid receptors with the G-protein activated K channel. Biochem Biophys Res Commun 208:302-308.

Kanemasa T, Asakura K, Ninomiya M (1995) $\kappa$-opioid agonist U50488 inhibits P type Ca channels by two mechanisms. Brain Res 702:207-212.

Lai HWL, Minami M, Satoh M, Wong YH (1995) $\mathrm{G}_{z}$ coupling to the rat $\kappa$-opioid receptor. FEBS Lett 360:97-99.

Law SF, Yasuda K, Bell GI, Reisine T (1993) $\mathrm{G}_{\mathrm{i} \alpha 3}$ and $\mathrm{G}_{\mathrm{o} \alpha}$ selectively associate with the cloned somatostatin receptor subtype SSTR2. J Biol Chem 268:10721-10727.

Lipscombe D, Kongsamut S, Tsien RW (1989) Alpha-adrenergic inhibition of sympathetic neurotransmitter release mediated by modulation of N-type calcium-channel gating. Nature 340:639-642.

Miller RJ (1990) The receptor mediated regulation of calcium channels and neurotransmitter release. FASEB J 4:3291-3300.

Mintz IM, Bean BP (1993) GABA-B receptor inhibition of P type Ca channels in central neurons. Neuron 10:889-998.

Perez-Reyes E, Yuan W, Wei X, Bers DM (1994) Regulation of cloned L-type cardiac calcium channels by cyclic AMP dependent protein kinase. FEBS Lett 342:119-123. 
Pragnell M, De Waard M, Mori Y, Tanabe T, Snutch TP, Campbell KP (1994) Calcium channel $\beta$ subunit binds to a conserved motif in the 1-11 cytoplasmic linker of the $\alpha_{1}$ subunit. Nature 368:67-70.

Reisine T, Bell G (1995) Molecular properties of somatostatin receptors. Neuroscience 67:777-790.

Rhim H, Miller RJ (1994) Opioid receptors modulate diverse types of calcium channels in the nucleus tractus solitarius of the rat. $\mathrm{J}$ Neurosci 14:7608-7615.

Robishaw JD, Russell DW, Harris, BA, Smigel MD, Gilman AG (1986) Deduced primary structure of the $\alpha$-subunit of the GTP-binding stimulatory protein of adenylate cyclase. Proc Natl Acad Sci USA 83:1251-1255.

Roche JP, Anantharam V, Treistman SN (1995) Abolition of G-protein inhibition of $\alpha_{1 \mathrm{~A}}$ and $\alpha_{1 \mathrm{~B}}$ calcium channels by coexpression of the $\beta 3$ subunit. FEBS Lett 371:43-46.

Sambrook J, Fritsch EF, Maniatis T (1989) Molecular cloning: a laboratory manual. Cold Spring Harbor, NY: Cold Spring Harbor Laboratory.

Schneider T, Wei X, Olcese R, Costantin JL, Neely A, Palade P, PerezReyes E, Qin N, Zhou J, Crawford GD, Smith RG, Appel SH, Stefani E, Birnbaumer L (1994) Molecular analysis and functional expression of the human type E neuronal Ca channel $\alpha_{1}$ subunit. Recept Channels 2:255-270.

Shapiro MS, Hille B (1993) Substance P and somatostatin inhibit calcium channels in rat sympathetic neurons via different $G$ protein pathways. Neuron 10:11-20.

Shen KF, Crain SM (1994) Nerve growth factor rapidly prolongs the action potential of mature sensory ganglion neurons in culture, and this effect requires activation of $\mathrm{G}_{\mathrm{s}}$ coupled excitatory $\kappa$-opioid receptors on these cells. J Neurosci 14:5570-5579.

Slesinger PA, Reuveny E, Jan YN, Jan LY (1995) Identification of structural elements involved in G-protein gating of the GIRK-1 potassium channel. Neuron 15:1145-1156.

Soong TW, Stea A, Hodson CD, Dubel SJ, Vincent SR, Snutch TP (1993) Structure and functional expression of a member of the low voltage activated calcium channel family. Science 260:1133-1136.

Sternweis PC (1994) The active role of $\beta / \gamma$ by in signal transduction. Curr Opin Cell Biol 6:198-203.

Tallent M, Dichter MA, Bell GI, Reisine T (1995) The cloned kappa opioid receptor couples to an N-type calcium current in undifferentiated PC-12 cells. Neuroscience 63:1033-1040.
Volsen SG, Day NC, McCormack AC, Smith W, Craig PJ, Beattie R, Incep G, Show PJ, Ellis SB, Gillespie A, Harpold MM, Lodge D (1995) The expression of neuronal voltage dependent $\mathrm{Ca}$ channels in human cerebellum. Mol Brain Res 34:217-232.

Wheeler DB, Randall A, Tsien RW (1994) Roles of N type and Q type Ca channels in supporting hippocampal synaptic transmission. Science 264:107-111.

Wheeler DB, Randall A, Sather WA, Tsien RW (1995) Neuronal calcium channels encoded by the $\alpha_{1 \mathrm{~A}}$ subunit and their contribution to excitatory synaptic transmission in the CNS. Prog Brain Res 105:65-78.

Wickman K, Clapham DE (1995) Ion channel regulation by G-proteins. Physiol Rev 75:865-885.

Williams ME, Brust PF, Feldman DH, Patthi S, Simerson S, Maroufi A, McCue AF, Velicelebi G, Ellis SB, Harpold MM (1992) Structure and functional expression of an $\omega$-conotoxin sensitive human $\mathrm{N}$-type calcium channel. Science 257:389-395.

Williams SM, Marubio LM, Deal CR, Hans M, Brust PF, Philipson LH, Miller RJ, Johnson EC, Harpold MM, Ellis SB (1994) Structure and functional characterization of neuronal $\alpha_{1 \mathrm{E}}$ calcium channels subtypes. J Biol Chem 269:22347-22357.

Yokoyama CT, Westenbroek RE, Hell JW, Soong T-W, Snutch TP, Catterall WA (1995) Biochemical properties and subcellular distribution of the neuronal class E calcium channel $\alpha_{1}$ subunit. J Neurosci 15:6419-6432.

Zhang J-F, Randall AD, Ellinor PT, Horne WA, Sather WA, Tanabe Schwarz TL, Tsien RW (1993) Distinctive pharmacology and kinetics of cloned neuronal $\mathrm{Ca}^{2+}$ channels and their possible counterparts in mammalian CNS neurons. Neuropharmacology 32:1075-1088.

Zhou J, Zong S, Tanabe T (1995) Modulation of cloned neuronal calcium channels through membrane delimited pathway. Biochem Biophys Res Commun 208:485-491.

Zhu Y, Ikeda SR (1994) VIP inhibits N type Ca channels of sympathetic neurons via a pertussis toxin insensitive but cholera toxin sensitive pathway. Neuron 13:657-669.

Zong S, Yassin M, Tanabe T (1995) G-protein modulation of $\alpha_{1 \mathrm{~A}}(\mathrm{P} / \mathrm{Q})$ type calcium channel expressed in GH3 cells. Biochem Biophys Res Commun 215:302-308. 